\title{
Sociolinguistic Studies: Phenomenon Of Diglosia In Postgraduate Students Of Indonesian Language And Literature Education Class Of 2020 University Of Muhammadiyah Purwokerto
}

\author{
Bella Allivia Sativa Turmono \\ \{bellaallivia21@gmail.com\} \\ English Education Department, Faculty of Teacher Training and Education, Universitas \\ Muhammadiyah Purwokerto
}

\begin{abstract}
Language is an arbriter sound symbol system, used by members of a community to work together, interact, and identify problems. Bahasa Indonesia is one of the languages that is often used to communicate and interact socially in the community in everyday life. Sociolinguistics is a science that studies characteristics and variations, as well as the relationship with the function characteristics of language variation itself in a language society. Diglosia is a language situation where there is a functional division of language variations in society. Research conducted on graduate students majoring in Indonesian language and literature education is qualitative research that is descriptive analysis through phenology approach. This research was conducted with the aim to find out related to the phenomenon of diglosia in postgraduate students majoring in Indonesian Language and Literature education class of 2020 in daily life. From the results of the analysis found that Bahasa Indonesia and Bahasa Jawa ragam $\mathrm{T}$ (Tinggi) are used when talking to lecturers and employees or during lectures. While Bahasa Indonesia and Bahasa Jawa ragam $\mathrm{R}$ (Low) are used when talking to peers.
\end{abstract}

Keywords: Language, Sociolinguistic, Diglosia, Bahasa Indonesia, Postgraduate Students

\section{Introduction}

Language is an arbriter sound lambing system, used by members of a community to work together, interact, and identify problems. Language is an organized communication tool in the form of units, such as words, groups of words, clauses, and sentences expressed both verbally and in writing. In this world, there are many languages and each language has its own system called grammar. There are also different grammars for foreign languages and Bahasa Indonesia. Communicating can indeed be done through any medium other than Language. Because in principle man will still communicate using language. In this context the language used is Human language. Basically, in the form of form, language is always in the form of text. Text means a linguistic unit that expresses meaning contextually.

Language has three main functions, namely ideasional functions, interpersonal functions, and textual functions. These three functions are commonly called metafunctionals. The ideaal function, Language is used to express physical-biological reality and to be related to the interpretation and representation of experience. Under interpersonal functions, Language is used 
to reveal social realities and deals with interactions between speakers/ writers and listeners/ readers. As for textual functions, Language is used to express semiotic realities or symbol realities and deals with the way text is created in context [1].

Bahasa Indonesia is one of the languages that is often used to communicate and interact socially in the community in everyday life. Iryani in her book [2] says that bahsam is a means of human communication in delivering messages between each other. In the field of education, Bahasa Indonesia is the main language used during the learning. However, people are more familiar with the language of the region compared to Bahasa Indonesia. This is because of the mother tongue or the first language they can get is their own regional language. So, Bahasa Indonesia becomes the second language for the community. The linguistic phenomenon that occurs in Indonesia, indirectly encourages people to be able to speak more than one language. Fishman [3] says that diglosia can happen to people who know one language with only two varieties but also in people who know more than two languages.

Sociolinguistics is a science that studies characteristics and variations, as well as the relationship with the function characteristics of language variation itself in a language society. Hidayati (2011) said that, Indonesians who master several languages tend to use several different languages in communicating, so indirectly this is what causes language variations. Indonesian society consisting of a variety of tribes, cultures and races led to the mixing of languages. It is also one of the causes of one's language [4]. Kedwibahasaan is one of the phenomena of two languages in a act of speech [5]. The occurrence of Language contact is due to the existence of language.

According to Ferguson (2016:571) diglosia is a situation about the existence of Language variations in a community and these variations play a defined function by the user. The variations in question are High language (H-High) and low language variation (L-Low) [6]. Halim in his book conveys that diglosia realizes a high language rating $(\mathrm{H})$ and low $(\mathrm{L})$ due to the purpose or function of its use and influenced by the user group of something language in a formal state or vice versa.

Diglosia is one of the studies in sociolinguistic science that discusses a phenomenon of language, especially the use of a variety of appropriate languages in the community. A Language has a specific code or variety or dialect used when communicating. This is in accordance with Iryani's statement (2017) that diglosia hamper is similar to bilingual but diglosia has a high language and low language (based on Fishman's theory) [7]. Language has a variety of verbal and non-verbal communication, people can use formal, informal and nonformal language, baku and nonbaku based on the function and hierarchy of the language speaker class [8]. According to Sunardi (2018) diglosia is a language situation where there is a functional division of language variants or languages in the community [9].

This diglosia phenomenon requires the speaker to choose the language used when interacting. According to Simatupang (2018:2) conveying related objects of sociolinguistic studies is the choice of languages that exist in the community of various languages such as people who master two or more languages that must be chosen at the time of speaking [10]. With the phenomenon of diglosia, it is expected that Bahasa Indonesia is still used properly and correctly. Knowledge of sociolinguistic science is also important to be given to the community so that the use of language in the community can still run properly and correctly. 


\section{Research Methods}

The method used in this study is qualitative research that is a description of analysis, which is an object of how different languages are used when talking to a person. Data collection techniques and data analysis, namely, (1) observing the state of students when speaking using Bahasa Indonesia, (2) collecting data, in the form of several sentences that are applied when speaking, (identifying data, the sentence falls into the category of variety of $\mathrm{T}$ language or variety of $\mathrm{R}$ language [11].

\section{Results and Discussion}

Postgraduate students of Indonesian Language and Literature education mostly use two languages in daily communication activities. Both languages are Javanese and Bahasa Indonesia. The languages used also have a variety of T (high) and R (low) languages. In Bahasa Indonesia, the variety of $\mathrm{T}$ is commonly used when in lectures, where the language is used to communicate with lecturers or employees. While Bahasa Indonesia with a variety of $\mathrm{R}$ is commonly used when outside lectures, such as the kind of communication with peers.

Language acquisition also varies, because not all students state that their native language is Bahasa Indonesia. More than 100,000 students have stated that their native language is Javanese. This happened because they were born in java, so the first language taught is baahasa Java, both in the variety of $\mathrm{T}$ and variety $\mathrm{R}[12]$.

The origin of the students' area also affects the ability to speak. Those who come from outside Java, claim to be quite difficult to accept the intentions of the interlocutor who uses Javanese language [13]. So, to overcome these problems, graduate students majoring in Indonesian Language and Literature education more often use Bahasa Indonesia in conversation or daily communication. It is different from Javanese people and their mother tongue is also Javanese, they will be easier to use and accept the intention of the interlocutor if using Javanese. However, it does not close the possibility that not all students can understand all Javanese accents. For example, Yogyakarta javanese accent with Javanese accent in Banyumas. There are differences especially in terms of phonology in the sentences used as follows:

Table 1. Example differences especially in terms of phonology in the sentences used as.

\begin{tabular}{|l|l|l|}
\hline \multicolumn{1}{|c|}{$\begin{array}{c}\text { Bahasa Jawa Ragam R } \\
\text { (Yogyakarta) }\end{array}$} & \multicolumn{1}{|c|}{$\begin{array}{c}\text { Bahasa Jawa Ragam R } \\
\text { (Banyumas) }\end{array}$} & \multicolumn{1}{c|}{ Arti } \\
\hline $\begin{array}{l}\text { Aku nyuwun pirsa, daleme Bu } \\
\text { Tri kuwi, neng ndi yo? }\end{array}$ & $\begin{array}{l}\text { Nyong arep takon, umaeh bu } \\
\text { Tri kuwe nang ndi ya? }\end{array}$ & $\begin{array}{l}\text { Saya mau bertanya, rumahnya } \\
\text { bu Tri di mana ya? }\end{array}$ \\
\hline $\begin{array}{l}\text { Sammpeyan tindak menyang } \\
\text { kampus? }\end{array}$ & $\begin{array}{l}\text { Kowe arep lunga } \\
\text { kampus? }\end{array}$ & Kamu mau pergi ke kampus? \\
\hline
\end{tabular}

Basically, in a society that uses several languages will definitely experience problems that are related to the function and position of the language contained in it. In the life of graduate students majoring in Indonesian language and literature education, the $T$ variety is used when communicating with older people and have positions. This variety of $\mathrm{T}$ is usually obtained from 
formal education. For example, with lecturers, study program chairmen, postgraduate directors, and so on. While the variety of $\mathrm{R}$ language is commonly used to communicate daily in most of the life of graduate students majoring in Indonesian language and literature education. This variety of $\mathrm{R}$ language is obtained from association with family and friends every day. There are several examples of sentences that are usually used by students as follows:

Table 2. Examples of sentences that are usually used by students

\begin{tabular}{|l|l|}
\hline \multicolumn{1}{|c|}{ Bahasa Indonesia Ragam T } & \multicolumn{1}{c|}{ Bahasa Indonesia Ragam R } \\
\hline $\begin{array}{l}\text { Mohon maaf mengganggu waktunya Pak, saya } \\
\text { mohon izin bertemu untuk mengkonsultasikan } \\
\text { terkait judul Tesis. }\end{array}$ & $\begin{array}{l}\text { Kamu sudah mengumpulkan } \\
\text { Tesis belum? }\end{array}$ \\
\hline $\begin{array}{l}\text { Permisi Bapak, ada yang ingin kami tanyaka } \\
\text { perihal tugas Pengembangan Kurikulum } \\
\text { Bahasa. }\end{array}$ & $\begin{array}{l}\text { Kamu sudah paham } \\
\text { tugas Pengembangan Kurikulum Bahasa atau } \\
\text { belum? }\end{array}$ \\
\hline $\begin{array}{l}\text { Mohon maaf Ibu, di tempat saya sedang terkendala } \\
\text { sinyal, sebab sedang turun hujan } \\
\text { deras sekali bersamaan dengan petir. }\end{array}$ & Apakah suaraku terdengar jelas di zoom? \\
\hline $\begin{array}{l}\text { Maaf Bu sebelumnya, tetapi untuk di waktu itu } \\
\text { kami sudah ada jadwal mata kuliah yang lain. }\end{array}$ & Besok kita sudah ada jadwal kuliah siapa ya? \\
\hline
\end{tabular}

Table 3. Examples of sentences that are usually used by students

\begin{tabular}{|l|l|}
\hline \multicolumn{1}{|c|}{ Bahasa Jawa Ragam T } & \multicolumn{1}{c|}{ Bahasa Jawa Ragam R } \\
\hline $\begin{array}{l}\text { Nuwun sewu, kulo badhe nyuwun pirsa, dalemipun } \\
\text { Bapak Direktur punika, wonten pundi nggih? } \\
\text { (Permisi, saya izin mau bertanya, rumah Bapak }\end{array}$ & $\begin{array}{l}\text { Ngko aja lali, balik kos-kosan ndisit yo (nanti } \\
\text { jangan lupa, pulang ke kos-kosan dulu ya) }\end{array}$ \\
Direktur, ada di mana ya? & \\
\hline $\begin{array}{l}\text { Sugeng enjing bapak, kulo badhe nyuwun } \\
\text { konsultasi nilai pripun nggih? }\end{array}$ & $\begin{array}{l}\text { Arep melu aku menyang kampus ora? } \\
\text { (mau ikut saya ke kampus tidak) }\end{array}$ \\
$\begin{array}{l}\text { (Selamat pagi Bapak, saya izin mau } \\
\text { konsultasi nilai bagaimana ya? }\end{array}$ & \\
\hline $\begin{array}{l}\text { Nuwun sewu Ibu Dosen, kulo badhe nyuwun } \\
\text { pirsa tugas (Permisi ibu dosen, saya izin mau } \\
\text { bertanya tugas) }\end{array}$ & $\begin{array}{l}\text { Koe ngopo dina iki ora mlebu? (kamu kenapa hari } \\
\text { ini tidak masuk? }\end{array}$ \\
\hline $\begin{array}{l}\text { Sugeng enjing Ibu, kulo badhe nyuwun kisi- } \\
\text { kisi ujian pripun nggih? (selamat pagi ibu, saya } \\
\text { izin mau meminta kisi-kisi untuk ujian } \\
\text { bagaimana ya? }\end{array}$ & $\begin{array}{l}\text { Aja lali, ngesuk ana ujian (jangan lupa, besok ada } \\
\text { ujian) }\end{array}$ \\
\hline
\end{tabular}

\section{Conclusion}

Postgraduate students majoring in Indonesian language and literature education can indirectly be mostly referred to as bilingualism. Because they are able to communicate with two languages, yaakni Bahasa Indonesia and Bahasa Jawa (their respective mother tongues). Some make Bahasa Indonesia as the mother tongue, but others make Javanese as the mother tongue. The use of Bahasa Indonesia variety of $\mathrm{T}$ language is used in formal situations and when communicating with older people. While in Javanese, the variety of $\mathrm{T}$ language is used to 
communicate with older people and have a position or position. The use of Bahasa Indonesia variety of $\mathrm{R}$ language is used in non-formal situations by communicating with older people. Various $\mathrm{R}$ languages in Javanese are used when communicating with peers.

\section{Reference}

[1] [Chaer, A., Agustina, L. (2004). Sosiolinguistik:Perkenalan Awal. Jakarta: Rineka Cipta

[2] Halim, M, Z, A., Yusoff, M, F, Md. (2016). Diglosia dalam Salina: Satu Kajian

[3] Hanafi, W. (2017). Diglosia Bahasa Arab Pesantren dan Upaya Pemertahanan Bahasa Daerah.

[4] Hidayati, Nurul. (2011). Variasi Bahasa pada Tuturan Guru Dansiswa Dalam Kegiatan Komunikasi dilingkungan MAN 3 Malang. Pendidikan Bahasa Indonesia. Fakultas Keguruan dan Ilmu Pendidikan. Universitas Muhammadiyah Malang.

[5] Iryani, E. (2017). Diglosia Antara Bahasa Jawa dan Sunda (Studi Kasus Masyarakat Bahasa Kecamatan Lemah Abang Kabupaten Cirebon). Jurnal Inovasi Pendidikan MH Thamrin. 1 (1), 1-6 ISSN: 2549-3310.

[6] QALAMUNA: Jurnal Pendidikan, Sosial, dan Agama, 9 (2), 47-70 ISSN: 1907-6355

[7] Saddhono, Kundharu. (2012). Kajian Sosiolingustik Pemakaian Bahasa Mahasiswa Asing Dalam

[8] Saddhono, Kundharu. (2012). Pengantar Sosiolinguistik Teori dan Konsep Dasar.Surakarta : Program Buku Teks LPP UNS

[9] Saddhono, Kundharu. (2014). Pengantar Sosiolingistik Teori dan Konsep Dasar. Surakarta: UNS Press.

[10] [Simatupang, R, R., Rohmadi, M., Saddhono, K. (2018) Tuturan dalam Pembelajaran Bahasa Indonesia (Kajian Sosiolinguistik Alih Kode dan Campur Kode. Kajian Lingistik dan Sastra, 3 (2), 119- 130.

[11] [Simatupang, R. R., Rohmadi, M., Saddhono, K. (2018). Alih Kode dan Campur Kode. Tuturan di Lingkungan Pendidikan LINGTERA, 5 (1), 1-9.

[12] Sunardi, A., Susanto, A. (2018). Diglosia Bahasa dalam Pelayanan Obat di Apotel Siti Hadjar PKU Muhammadiyah Tegal. Jurnal Politeknik Harapan Bangsa Tegal, 7 (2), 244-246. 